\title{
The Impacts of Sino-US Trade on China's Economic Growth
}

\author{
Hao Xie \\ Shanghai-Hongkong Development Institute, Fudan University, Shanghai, China \\ Email: xiehao1978@hotmail.com
}

Received 22 April 2014; revised 22 May 2014; accepted 12 June 2014

Copyright (C) 2014 by author and Scientific Research Publishing Inc.

This work is licensed under the Creative Commons Attribution International License (CC BY). http://creativecommons.org/licenses/by/4.0/

c) (i) Open Access

\begin{abstract}
China has witnessed many exciting changes after the Chinese government adopted reform and opening-up policy in 1978. In this process, the United States has a positive influence on China's economic growth. Traditional view thinks that the influence of exports on China's GDP growth is greater than imports, but the result of regression analysis shows that imports have a greater impact on China's GDP growth rather than the exports. Based on the statistics from 1998-2007, China's GDP will increase by $\mathbf{0 . 4 5 5 \%}$ if the volume of China's exports to US increases by $1 \%$ while China's GDP will increase by $0.825 \%$ if the volume of China's imports from US increases by $1 \%$.
\end{abstract}

\section{Keywords}

China, The United States, Economic Growth

\section{Introduction}

Since the Chinese government adopted reform and opening-up policy in 1978, bilateral trade has become an important way for China and the United States to communicate with each other. Therefore, the economic influence of the United States cannot be ignored in the process of China's economic growth.

Andrea believes that the international trade could guarantee the process of capital accumulation and promote economic growth [1]. Lewer and Berg also believe that free trade obviously has a positive influence on economic growth [2]. Dong compares the development track of China's foreign trade and China's economic growth and concludes that there is a two-way causal relationship between China's foreign trade and China's economic growth [3]. While Yao thinks that there is no generally accepted method which can be used to measure the impact of foreign trade on China's GDP growth [4]. Shen and Gu hold the point of view that China should not simply rely on the exports of labor-intensive products and on the processing trade to promote its trade and GDP. Instead, China should move toward producing technology-intensive and capital-intensive products [5]. 
This paper will analyze the relations between China's economic growth and Sino-US trade. The paper uses the economic statistics from 1997-2008 for the following reasons. Firstly, the Asian Financial Crisis occurred in 1997 and it seriously affected China's normal trade with other countries in the next year. In order to safeguard regional security and stability, the Chinese government made a painful decision not to devalue the RMB, which imposed China tremendous pressure. At the same time, the Chinese government changed its economic policy to expand domestic demand and stimulate economic growth in order to ensure the stability of RMB exchange rate. Secondly, Chinese economy slowed down after the Asian Financial Crisis for the Chinese government adopted the deflation economic policy, which can be seen as a turning point in the history of Chinese economy. Thirdly, the year of 2008 witnessed the global financial crisis resulted from the subprime mortgage crisis in the United States. The real economy around the whole world has immense downward momentum under the influence of that. Hence a new round of trade relations between China and the United States began after the year of 2008. Thus, this paper chooses a time series model from 1998 to 2007. The statistics can reflect economic relations between China and the United States as well as the impact of the Sino-US trade on China's economic growth during this period.

\section{The Relations between China's Economic Growth and Sino-US Trade Volume}

In order to make an in-depth analysis of the relations between China's economic growth and Sino-US trade volume, this paper adopts the annual data of Chinese GDP, Sino-US total trade and China's exports and imports to the United States (see Table 1).

Firstly, three line graphs (see Figures 1-3) are made on the basis of the above statistics. It is not difficult to find that all of the four variables (China's GDP, total trade with US, China's exports to US and China's imports from US) have shown an upward trend. What is more, their fluctuations and trends are quite similar. Thus, a hypothesis can be put forward that there is some inner relation between the above four variables. Secondly, in order to test if China's GDP has a linear relationship with the volume of total trade with US or China's exports to US or the volume of China's imports from US, three scatter plots can be made (see Figures 4-6) and the result shows that China's GDP has a linear relationship with the volume of total trade with US, the volume of China's export to US and the volume of China's imports from US. After analyzing the line graphs and scatter plots, it can be concluded that China's GDP does have a linear relationship with the volume of total trade with US, the volume of China's export to US and the volume of China's imports from US, Moreover, the figure shapes of the graphs and plots can also be described. However, the problem lies in the degree of closeness between each other. In that case, the correlation coefficient between China's GDP and the volume of total trade with US or the volume of China's exports to US or the volume of China's imports from US should be figured out in order to verify the hypothesis.

Table 1. China’s GDP and China’s trade with the United States from 1998 to 2007 (\$ billion).

\begin{tabular}{lcccc}
\hline & China's GDP & Total Trade with US & China's Exports to US & China's Imports from US \\
\hline $\mathbf{1 9 9 8}$ & 1019.5 & 85.5 & 71.2 & 14.3 \\
$\mathbf{1 9 9 9}$ & 1083.3 & 94.9 & 81.8 & 13.1 \\
$\mathbf{2 0 0 0}$ & 1198.5 & 116.3 & 100.0 & 16.3 \\
$\mathbf{2 0 0 1}$ & 1324.8 & 121.5 & 102.3 & 19.2 \\
$\mathbf{2 0 0 2}$ & 1453.8 & 147.3 & 125.2 & 22.1 \\
$\mathbf{2 0 0 3}$ & 1641.0 & 180.8 & 152.4 & 28.4 \\
$\mathbf{2 0 0 4}$ & 1931.6 & 231.4 & 196.7 & 34.7 \\
$\mathbf{2 0 0 5}$ & 2243.7 & 285.3 & 243.5 & 41.8 \\
$\mathbf{2 0 0 6}$ & 2644.6 & 343.0 & 287.8 & 55.2 \\
$\mathbf{2 0 0 7}$ & 3250.8 & 386.7 & 321.5 & 65.2 \\
\hline
\end{tabular}

Sources: International Monetary Fund \& US International Trade Commission, US Department of Commerce, and US Census Bureau. 


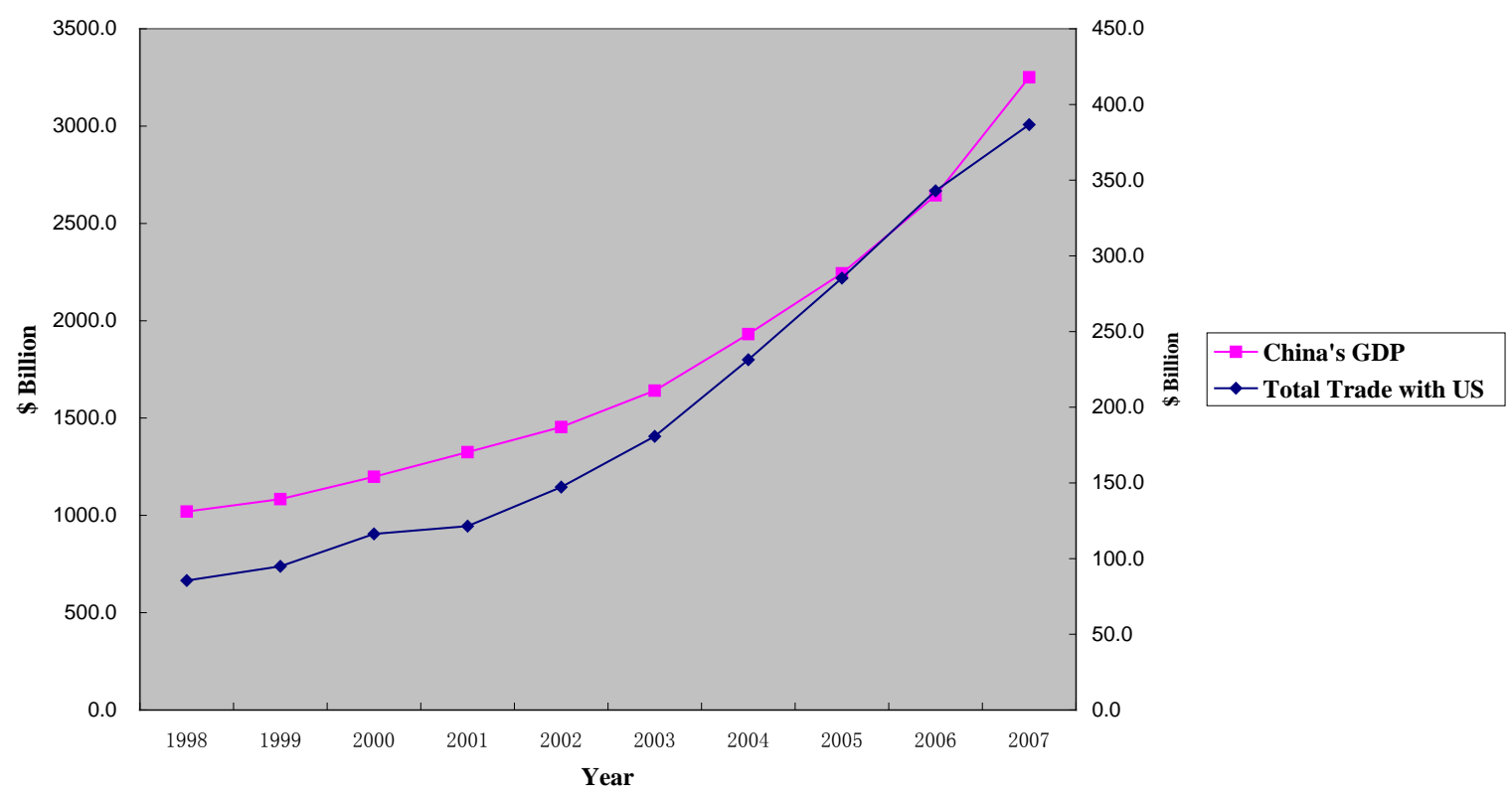

Figure 1. China's GDP \& total trade with US.

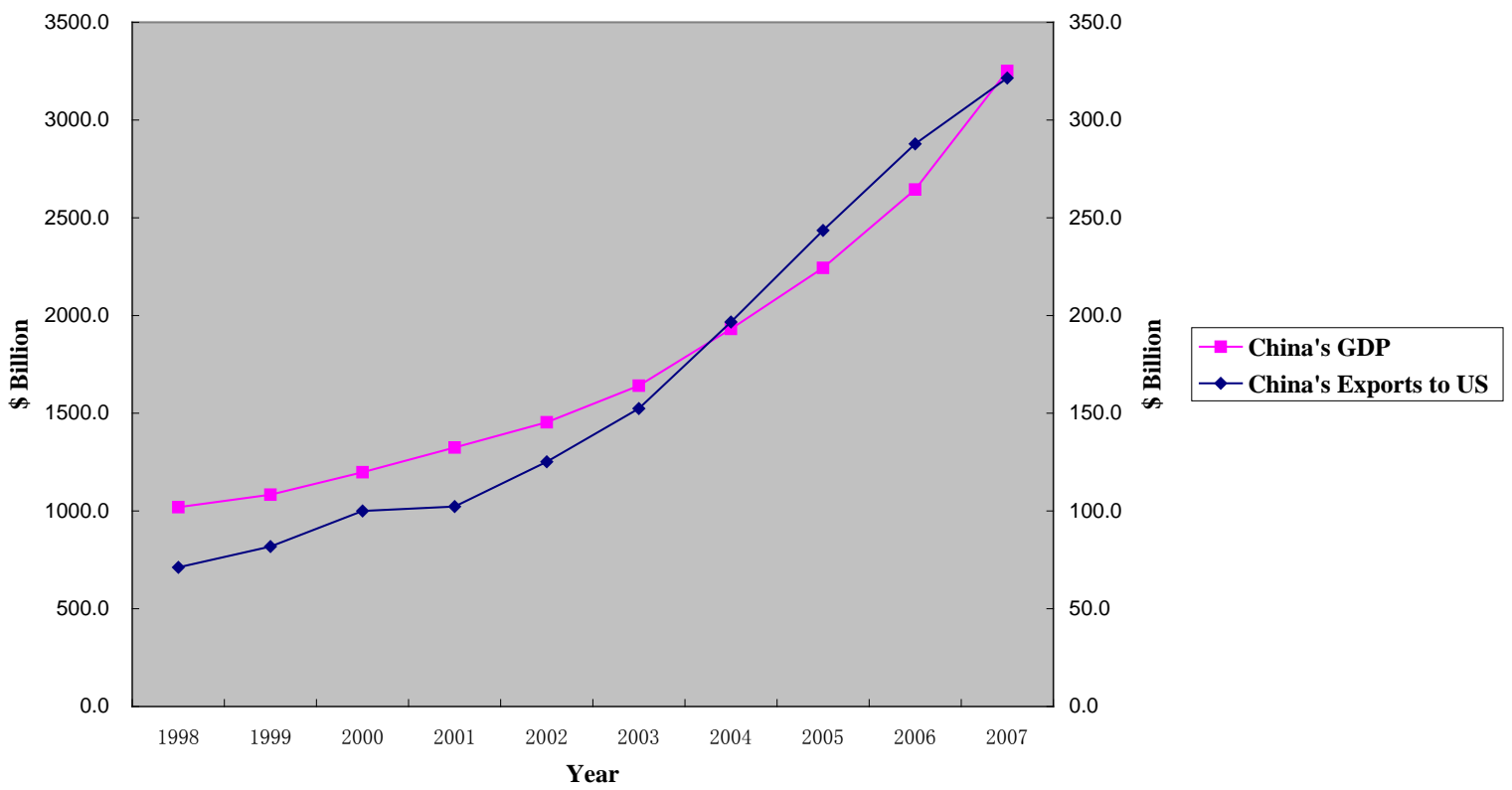

Figure 2. China's GDP \& China’s exports to US.

\section{How to Determine the Correlation Coefficient between China's GDP and Sino-US Trade Volume}

The Correlation Coefficient can show the strength and direction of linear relations between two random variables. The formula of Correlation Coefficient Formula is:

$$
r=\frac{\frac{\sum(x-\bar{x})(y-\bar{y})}{\sqrt{\frac{\sum(x-\bar{x})^{2}}{n}} \sqrt{\frac{\sum(y-\bar{y})^{2}}{n}}}}{\sqrt{\frac{\sum}{n}}}
$$

Note: $n$ represents the number of items; $x$ is independent variable and $y$ is dependent variable. 


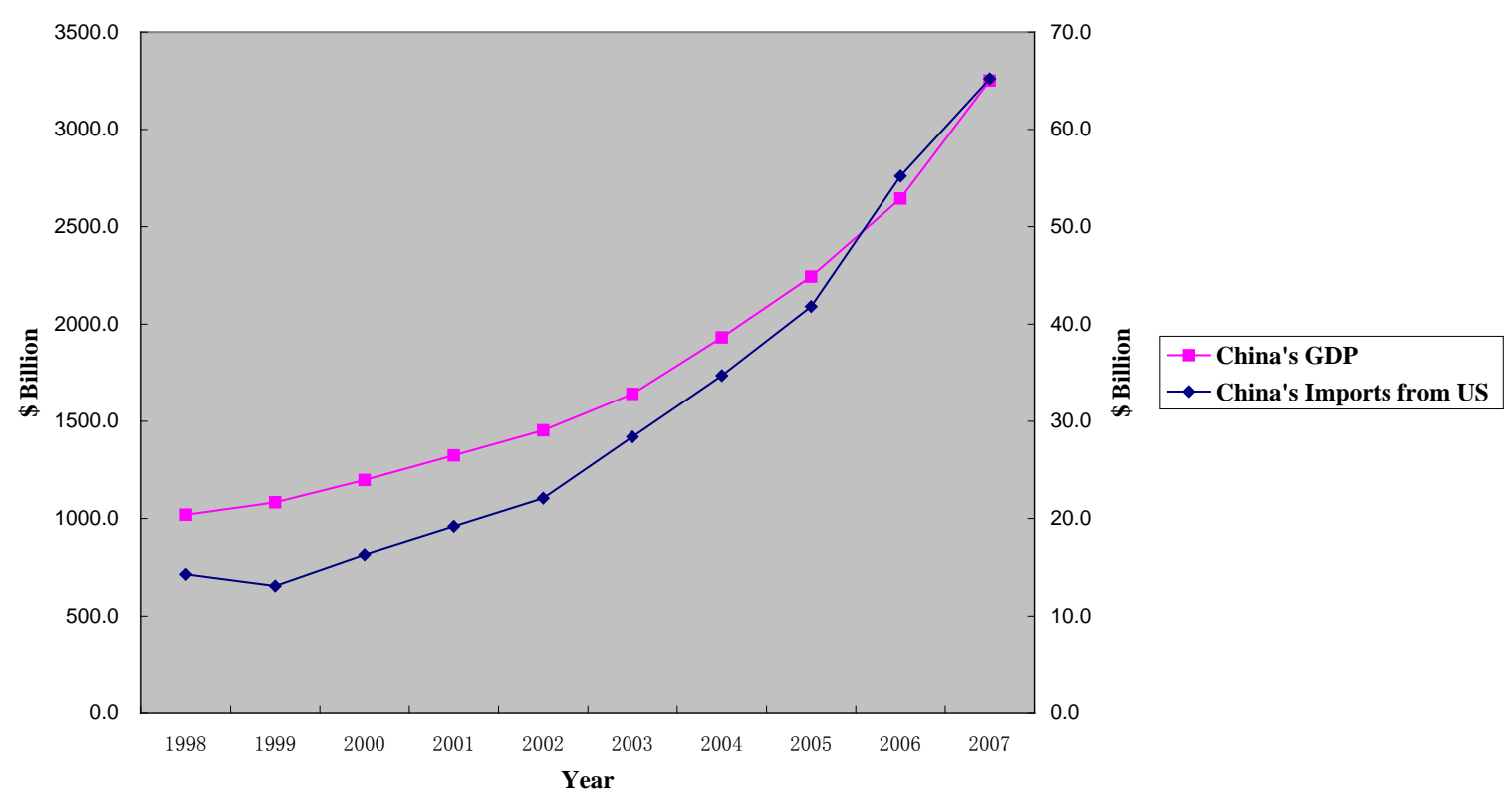

Figure 3. China’s GDP \& China’s imports from US.

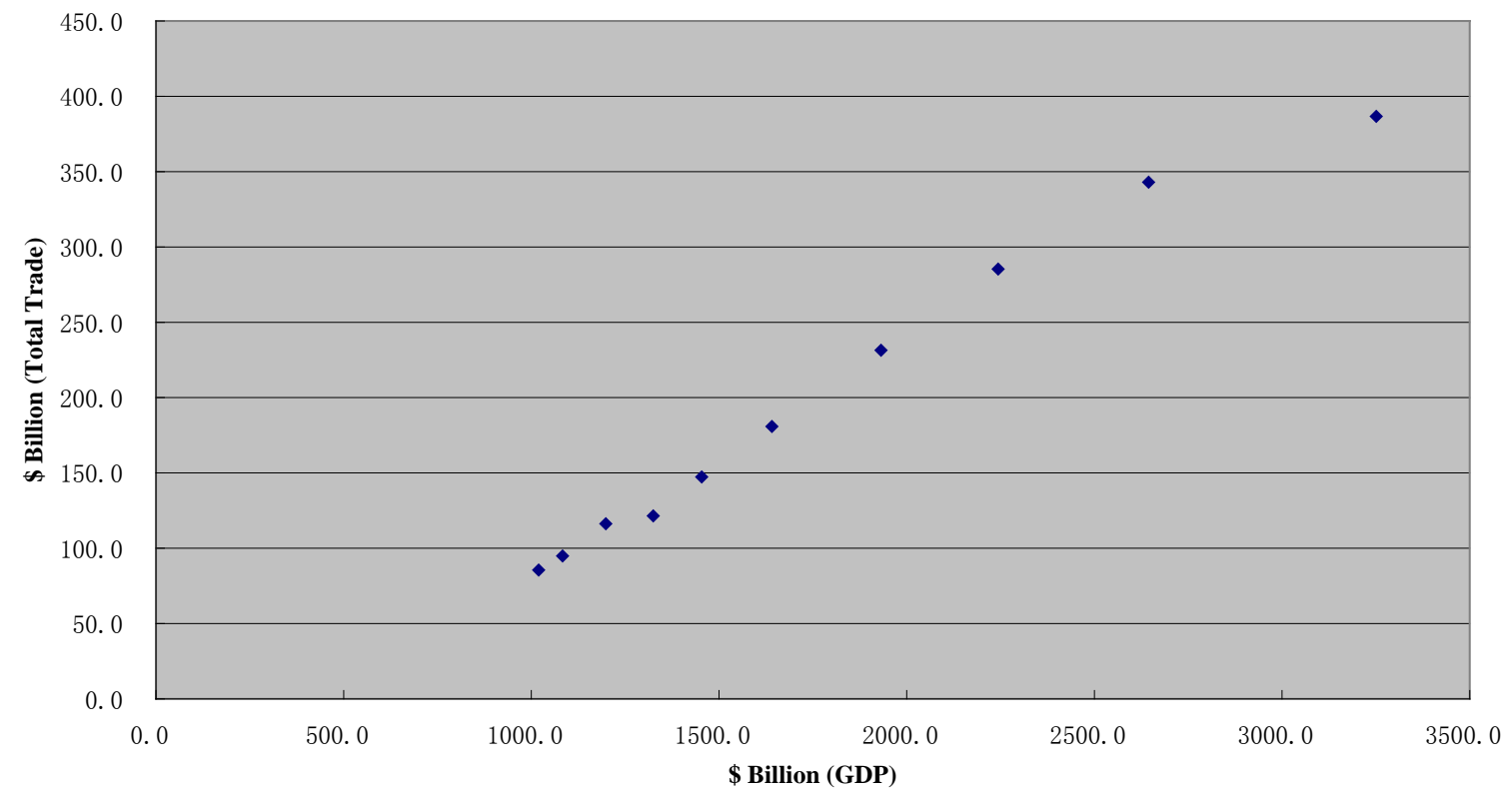

\section{Figure 4. China’s GDP \& total trade with US.}

This paper calculates the Correlation Coefficient between China's GDP and the volume of total trade with US and the result shows that the Correlation Coefficient between them is 0.992 . It is necessary to carry out the correlation test. The paper assumes that there is no linear relationship between China's GDP and the volume of total trade with US:

$$
\begin{gathered}
H_{0}: \rho=0, H_{1}: \rho \neq 0 \\
T=\frac{r \sqrt{n-2}}{\sqrt{1-r^{2}}}
\end{gathered}
$$

Note: The paper use two-tailed tests and set a statistical significance level at 0.05 .

After calculating relative data, the result proves that the value of $T$ is much bigger than the value of $t_{\alpha / 2}$, and 


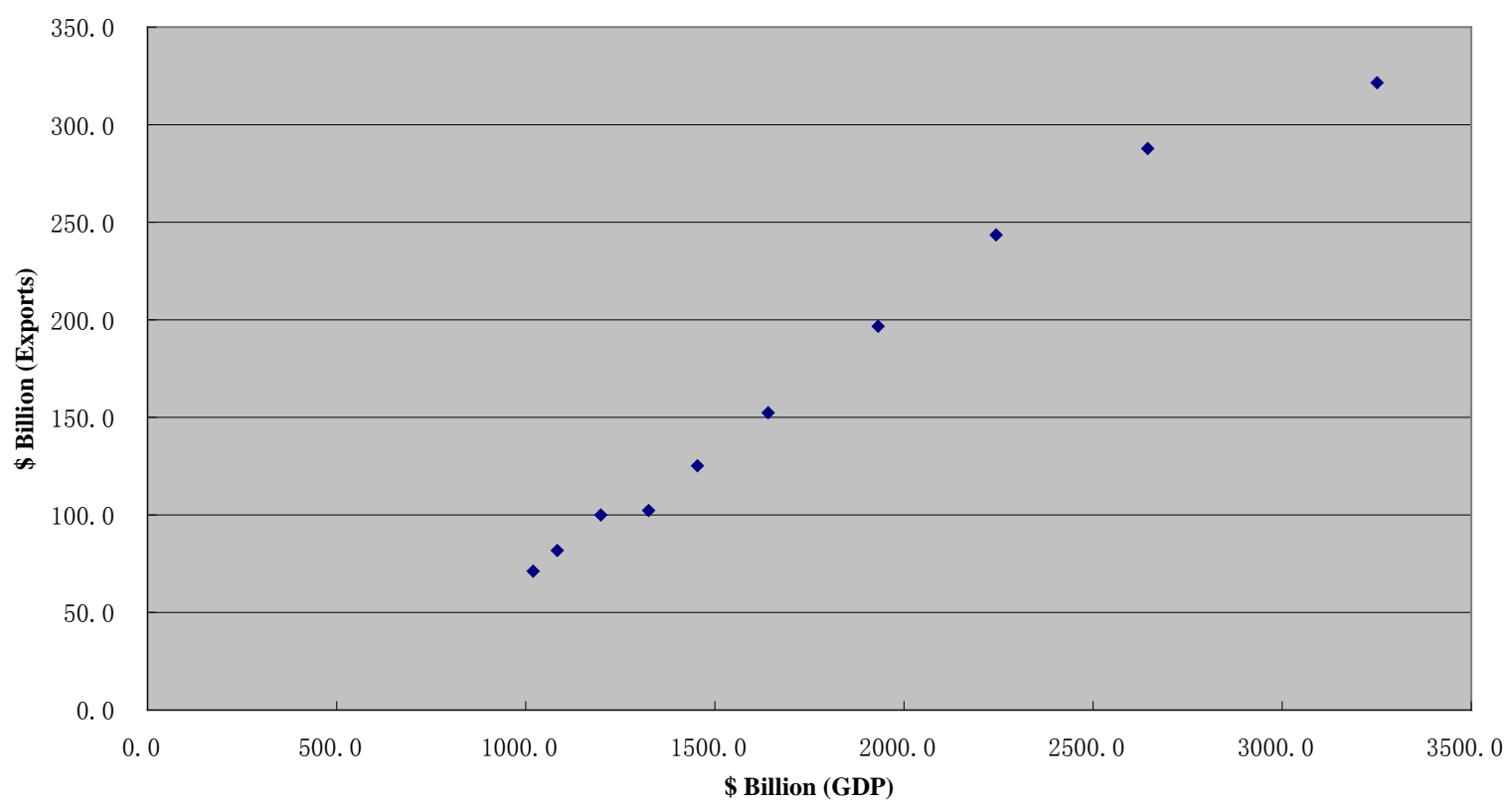

Figure 5. China’s GDP \& China’s exports to US.

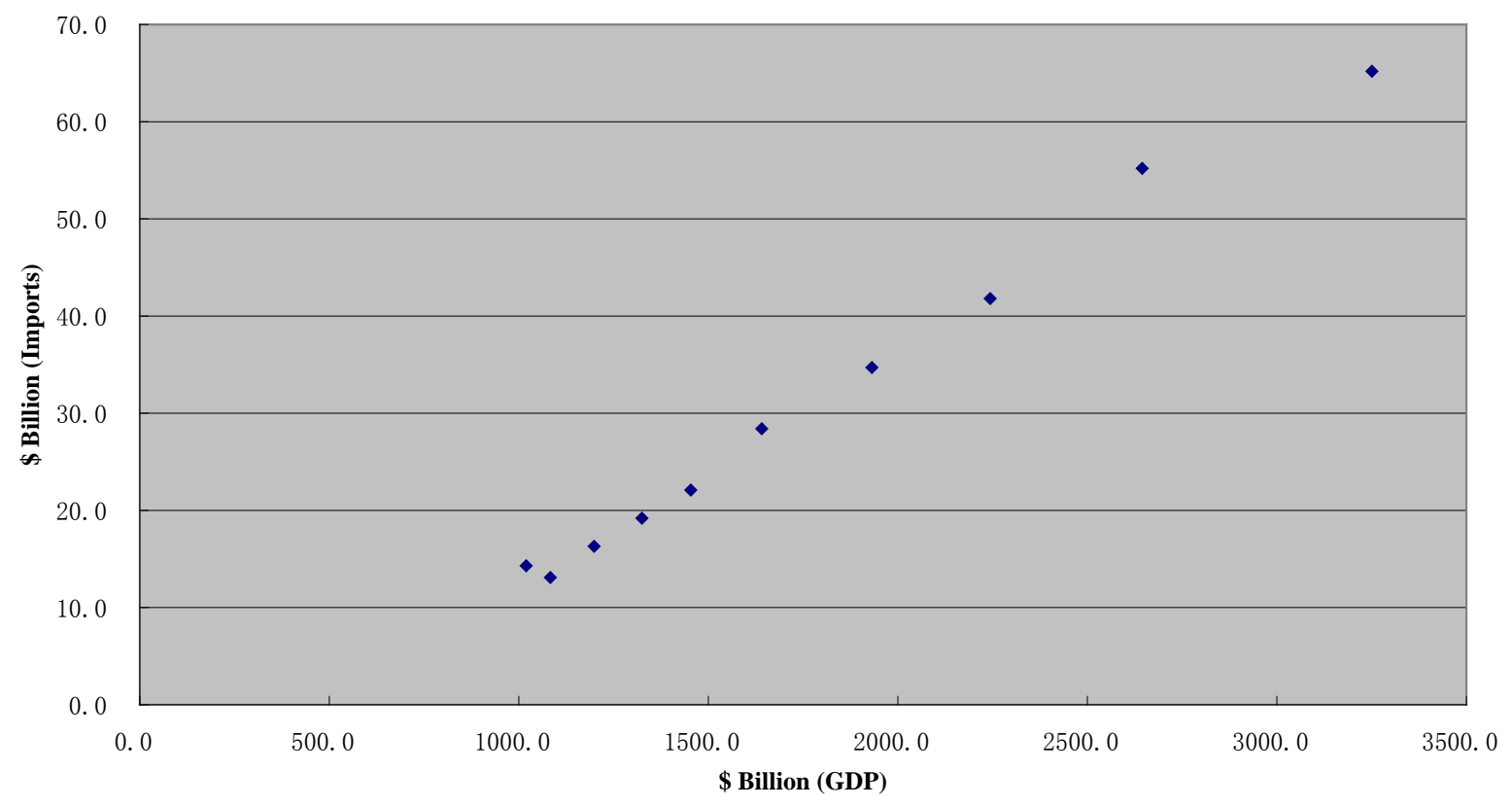

\section{Figure 6. China’s GDP \& China’s imports from US.}

P-value is $1.7366 \mathrm{E}-08$, which is significantly less than 0.05 . Both results do not meet the original assumption. Thus, a conclusion can be made that there is a high positive correlation between China's GDP and the volume of total trade with US. The paper also uses the same research method to calculate the Correlation Coefficient between China’s GDP and China's exports to US and the Correlation Coefficient between China's GDP and China's imports from US. The Correlation Coefficient between China's GDP and China's exports to US is 0.990. After carrying out the correlation text, the value of $T$ is much bigger than the value of $t_{\alpha / 2}$ and the P-value, 4.68376E-08, which is also obviously less than 0.05 .

The Correlation Coefficient between China's GDP and China's imports from US is 0.997. The results show that the value of $T$ is still bigger than the value of $t_{\alpha / 2}$ and this P-value is $5.11328 \mathrm{E}-10$ which is also significantly less than 0.05 . Therefore, this correlative analysis indicates that the high positive correlation can be ob- 
served not only between China's GDP and China's exports to US but also between China's GDP and China's imports from US. Here, it is worth noting that the Correlation Coefficient of China's GDP and China's imports from US, 0.997, is the highest among those three different Correlation Coefficients.

\section{A Regression Analysis between China's GDP and Sino-US Trade Volume}

The analyses of Correlation Coefficient of China's GDP, China's exports to US and China's imports from US have proven that there are three different kinds of high positive correlations between them. Thus, it is possible to use the method of Ordinary Least Square (OLS) to make a regression analysis (see Table 2). Firstly, it is assumed that the influence of other factors on China's economic growth is stable. Secondly, China's GDP is regarded as a dependent variable and the total trade with US is also regarded as an independent variable. Then, a simple linear regression model is created:

$$
\begin{aligned}
& y_{c}=a+b x \\
& \left\{\begin{array}{l}
b=\frac{n \sum x y-\sum x \sum y}{n \sum x^{2}-\left(\sum x\right)^{2}}=\frac{\overline{x y}-\bar{x} \cdot \bar{y}}{\sigma^{2}} \\
a=\frac{\sum y}{n}-b \frac{\sum x}{n}=\bar{y}-b \bar{x}
\end{array}\right. \\
& \text { Note: } \overline{x y}=\frac{\sum x y}{n}
\end{aligned}
$$

According to the data of Table 2, the R Square is 0.984 . The value of $\mathrm{F}$ is 496.746 which is big enough. The result of the test for linear relation indicates that the regression effect of the simple linear regression model is significant. Moreover, both results of t-test (22.288) and P-value (1.7366E-08) reveal that the influence of one independent variable on the other dependent variable is significant. In other words, China's total trade with US does have a significant influence on China's GDP. Therefore, a simple linear regression model is figured out which reflects predictable relations between China's GDP and its total trade with US:

$$
y_{c}=424.726+6.797 x
$$

or

China's GDP $=424.726+6.797$ Total Tarde with US

Similarly, Ordinary Least Square (OLS) can be taken to make regression analysis and calculate other two kinds of simple linear regression models. It is still assumed that the influence of other factors on China's eco-

Table 2. Regression analysis of China’s GDP and total trade with US (1998-2007).

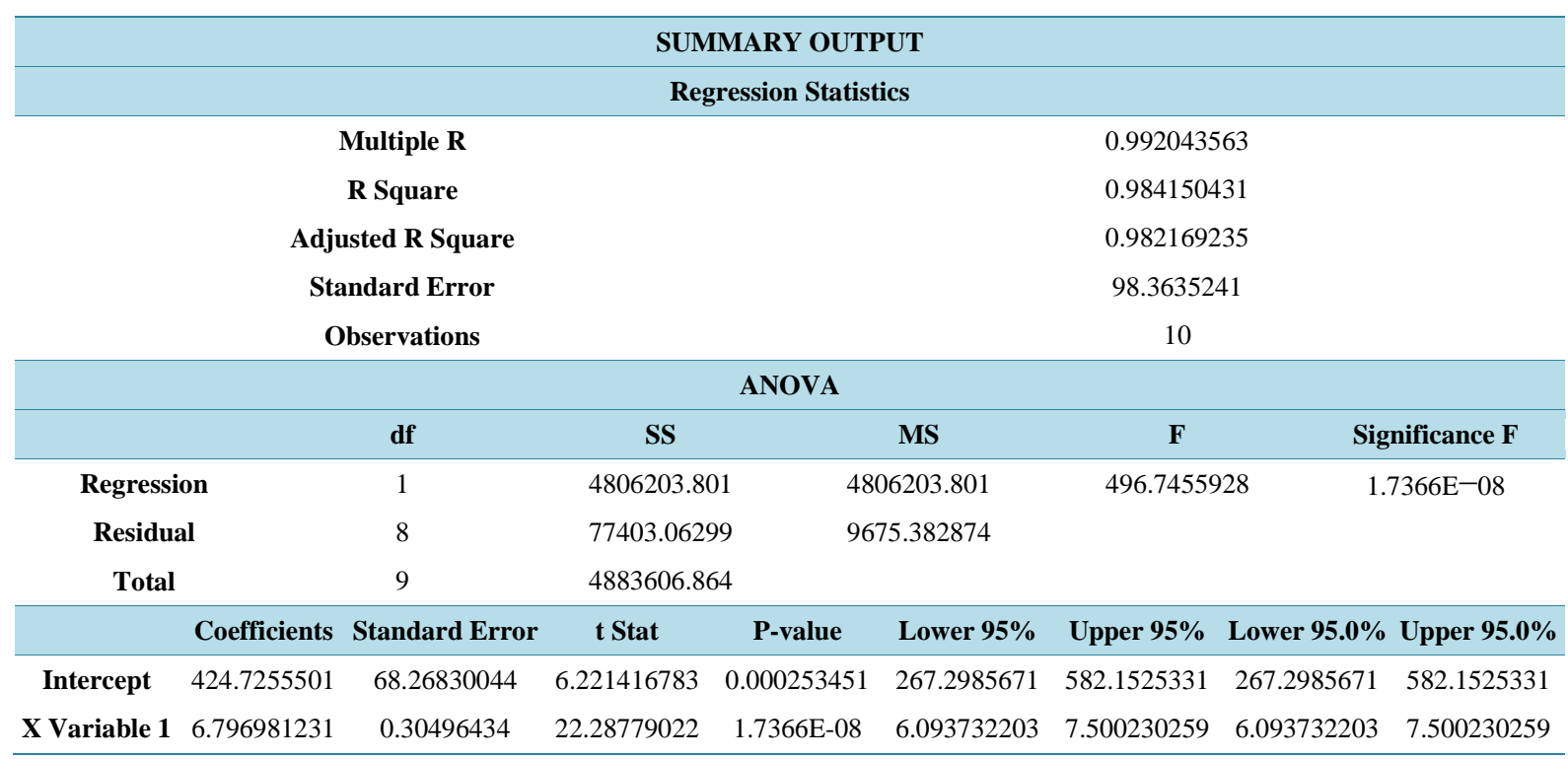


nomic growth is stable. Next, China's GDP is seen as a dependent variable and the volume of China's exports to US is also seen as an independent variable, or China's GDP is regarded as a dependent variable and China's imports from US is regarded as an independent variable.

In this case, the following simple linear regression models can be made.

China's GDP $=410.125+8.137$ China's Exports to US

China's GDP $=515.680+40.718$ China's Imports from US

If these simple linear regression models are analyzed only from the perspective of mathematics, China's GDP will increase by an average of $\$ 6.797$ billion if the volume of total trade with US increases by $\$ 1$ billion; China’s GDP will increase by an average of $\$ 8.137$ billion if the volume of China's exports to US increases by $\$ 1$ billion; China's GDP will increase by an average of $\$ 40.718$ billion if the volume of China's imports from US increases by $\$ 1$ billion. The information shows that the correlation between China's GDP and China's imports from US is stronger than the correlation between China's GDP and China's exports to US or between China's GDP and total trade with US Moreover, its regression coefficient is 40.718 which is 32.581 higher than the regression coefficient of China's GDP and China's exports to US.

\section{A Re-Examination of the Regression Analysis between China's GDP and Sino-US Trade Volume}

However, the period from 1998 to 2007 may not a good time series for it only has ten observations. So, it is necessary to choose a long time series to test whether the same result can be reached that the correlation between China's GDP and China's imports from US is stronger than the correlation between China's GDP and China's exports to US. In that case, a longer span from 1978 to 2007 is chosen for the test (see Table 3). Two line graphs are made in the same way (see Figure 7, Figure 8). It is obvious to notice that the upward trend of China's GDP is quite similar with the trend of China's exports to US and the trend of China's imports from US. So it is reasonable to assume there are some relations among those variables during that period.

Then, in order to test whether China's GDP has linear relations with the volume of China's exports to US and the volume of China's imports from US, this paper makes two scatter plots using the same data (see Figure 9, Figure 10). Compared with the data of Sino-US trade from 1998 to 2007, the data of Sino-US trade from 1978 to 2007 still shows us the similar result that the arrangements are tending to become straight lines except for a few points. Although time series has been extended to thirty years, it still can be concluded that the growth of China's GDP has linear relations with the volume of China's exports to US and the volume of China's imports to US in this period.

Since China's GDP also has a linear relationship with the volume of China's export to US and the volume of China's imports to US during that period. The correlation coefficient among them can be calculated (see Table 4, Table 5).

From 1978 to 2007, the Correlation Coefficient of China's GDP and China's exports to US is 0.993. After carrying out the correlation text, it shows the value of $T$ is much bigger than the value of $t_{\alpha / 2}$ and the P-value is $1.22612 \mathrm{E}-27$, which is obviously less than 0.05 . During the same period, the Correlation Coefficient of China's GDP and China's imports from US is 0.987. Its value of $T$ is also bigger than the value of $t_{\alpha / 2}$ and this $\mathrm{P}$-value is $1.46922 \mathrm{E}-23$ which is significantly less than 0.05 . Thus, the result of correlative analysis indicates hat, from 1978 to 2007, the high positive correlation can be observed not only between China's GDP and China's exports to US but also between China's GDP and China's imports from US. It can be also noticed notice that, during this period, the Correlation Coefficient of China's GDP and China's exports to US, 0.993, is higher than the Correlation Coefficient of China's GDP and China's imports from US.

Next, Ordinary Least Square (OLS) is applied to make regression analysis and calculate simple linear regression models. First, it is assumed that the influence of other factors on China's economic growth is stable. Second, China's GDP is seen as a dependent variable and the volume of China's exports to US is seen as an independent variable, or China's GDP is regarded as a dependent variable and the volume of China's imports from US is regarded as an independent variable. Therefore, the following simple linear regression models can be made:

China's GDP $=241.148+8.435$ China's Exports to US

China's GDP $=146.776+49.639$ China's Imports from US

From the perspective of mathematics, these two models indicate that China's GDP will increase by an average of $\$ 8.435$ billion if the volume of China's exports to US increases by $\$ 1$ billion; China's GDP will increase by 
Table 3. China’s GDP and China’s trade with the United States from 1978 to 2007 (\$ billion).

\begin{tabular}{|c|c|c|c|}
\hline & China's GDP & China's Imports from US & China's Exports to US \\
\hline 1978 & 147.3 & 0.8 & 0.4 \\
\hline 1979 & 175.6 & 1.7 & 0.7 \\
\hline 1980 & 188.2 & 3.8 & 1.2 \\
\hline 1981 & 193.0 & 3.6 & 2.1 \\
\hline 1982 & 202.1 & 2.9 & 2.5 \\
\hline 1983 & 227.4 & 2.2 & 2.5 \\
\hline 1984 & 256.1 & 3.0 & 3.4 \\
\hline 1985 & 304.9 & 3.8 & 4.2 \\
\hline 1986 & 295.7 & 3.1 & 5.2 \\
\hline 1987 & 268.2 & 3.5 & 6.9 \\
\hline 1988 & 307.2 & 5.0 & 9.2 \\
\hline 1989 & 342.3 & 5.8 & 12.8 \\
\hline 1990 & 354.6 & 4.8 & 16.3 \\
\hline 1991 & 376.6 & 6.3 & 20.3 \\
\hline 1992 & 418.2 & 7.5 & 27.5 \\
\hline 1993 & 440.5 & 8.8 & 33.7 \\
\hline 1994 & 559.2 & 9.3 & 41.3 \\
\hline 1995 & 728.0 & 11.7 & 48.5 \\
\hline 1996 & 856.1 & 12.0 & 54.4 \\
\hline 1997 & 952.7 & 12.8 & 65.8 \\
\hline 1998 & 1019.5 & 14.3 & 75.1 \\
\hline 1999 & 1083.3 & 13.1 & 87.8 \\
\hline 2000 & 1198.5 & 16.3 & 107.6 \\
\hline 2001 & 1324.8 & 19.2 & 109.4 \\
\hline 2002 & 1453.8 & 22.1 & 133.5 \\
\hline 2003 & 1641.0 & 28.4 & 163.3 \\
\hline 2004 & 1931.6 & 34.7 & 210.5 \\
\hline 2005 & 2243.9 & 41.8 & 259.8 \\
\hline 2006 & 2644.7 & 55.2 & 305.8 \\
\hline 2007 & 3250.8 & 65.2 & 340.1 \\
\hline
\end{tabular}

Source: The World Bank Group \& United Nations Commodity Trade Statistics Database.

an average of $\$ 49.639$ billion if the volume of China's imports from US increases by $\$ 1$ billion. Comparing those simple linear regression models (1978-2007) with the former simple linear regression models (1998-2007), the results are quite similar. From 1978 to 2007, the correlation between China's GDP and China's imports from US is still much stronger than the correlation between China's GDP and China's exports to US. Its regression coefficient is 49.639, 41.203 higher than the regression coefficient of China's GDP and China's exports to US. And, in order to make a deep comparison between the impact of China's imports from US and China's exports to US on China's GDP respectively, we can get the following Table 6.

After that, Ln (China's GDP) is regarded as a dependent variable and Ln (China's exports to US) is regarded as an independent variable. In the same way, China's GDP is seen as a dependent variable and China's imports from US are seen as an independent variable. Then, the following models are made on the basis of the regression analyses:

$$
\begin{gathered}
\text { Ln }(\text { China's GDP })=4.947+0.455 \text { Ln (China’s Exports to US) } \\
\operatorname{Ln}(\text { China's GDP })=4.599+0.825 \text { Ln (China's Imports from US) }
\end{gathered}
$$




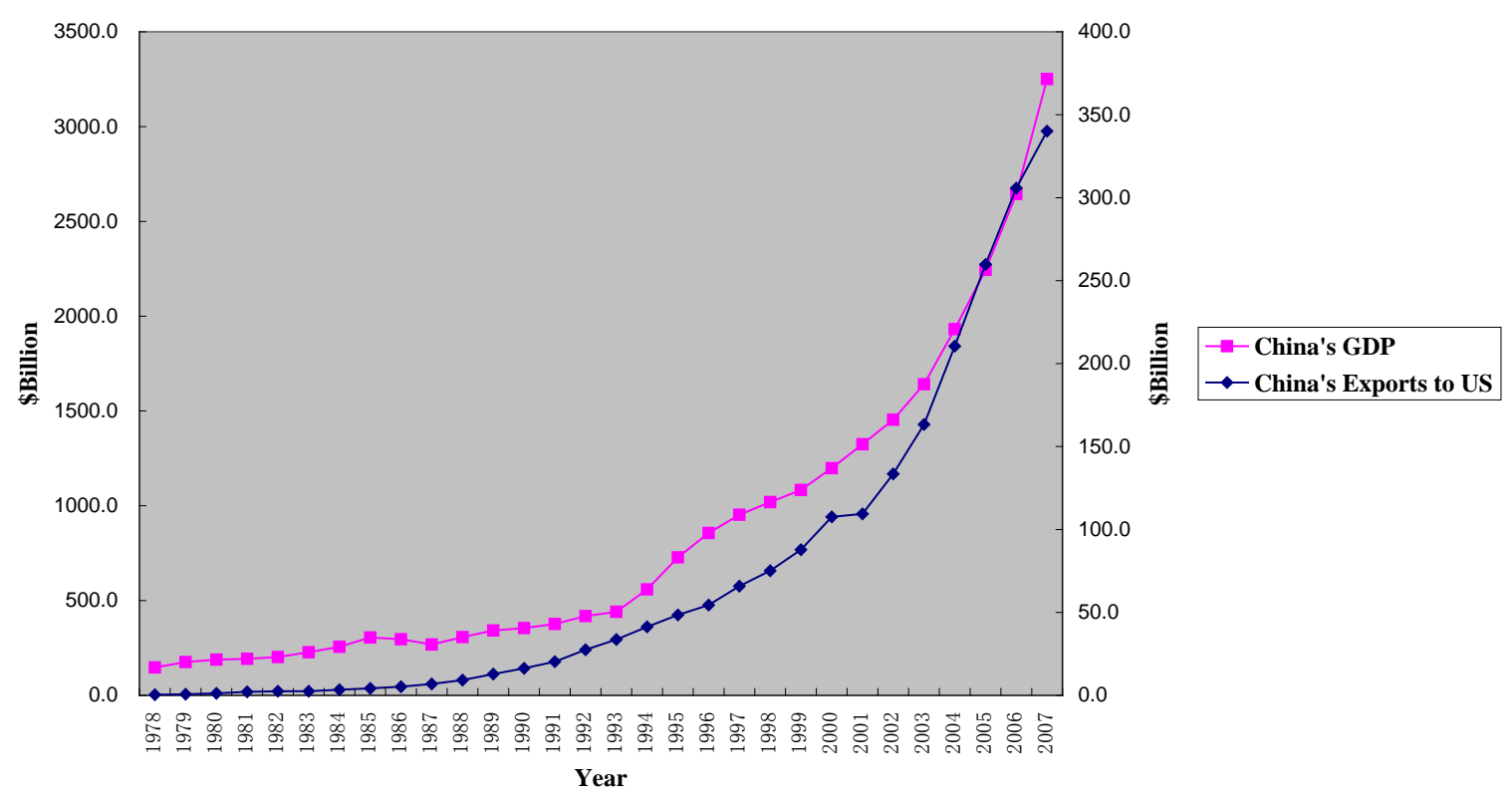

Figure 7. China’s GDP \& China’s exports to US.

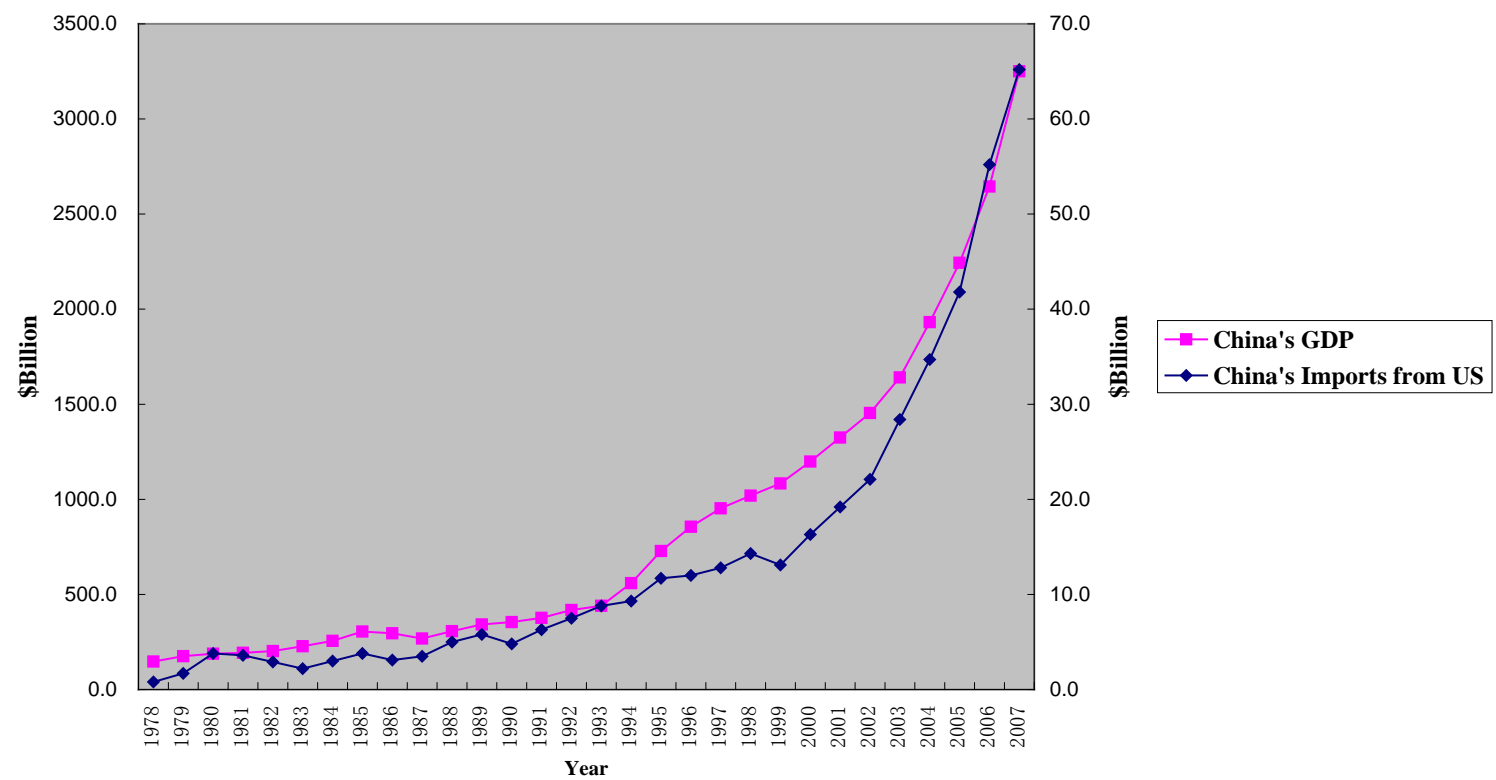

Figure 8. China’s GDP \& China’s imports from Us.

The two models indicate that China's GDP will increase by $0.455 \%$ if the volume of China's exports to US increases by 1\%; China's GDP will increase by $0.825 \%$ if the volume of China's imports from US increases by 1\%. Therefore, both two the researches of 10-year time series (1998-2007) and 30-year time series (1978-2007) yield the same result that, if these models are analyzed only from the perspective of mathematics and other factors are not considered, the influence of China's imports from US on China's GDP growth is much bigger than the influence of China's exports to US on it.

\section{Conclusions}

The Sino-US trade relations can be regarded as one of the most important trade relations in the world. Both China and the United States should attach great importance to the bilateral trade relations if they want to maintain stable economic growth in both countries. The main purpose of this paper is to analyze the relations be- 


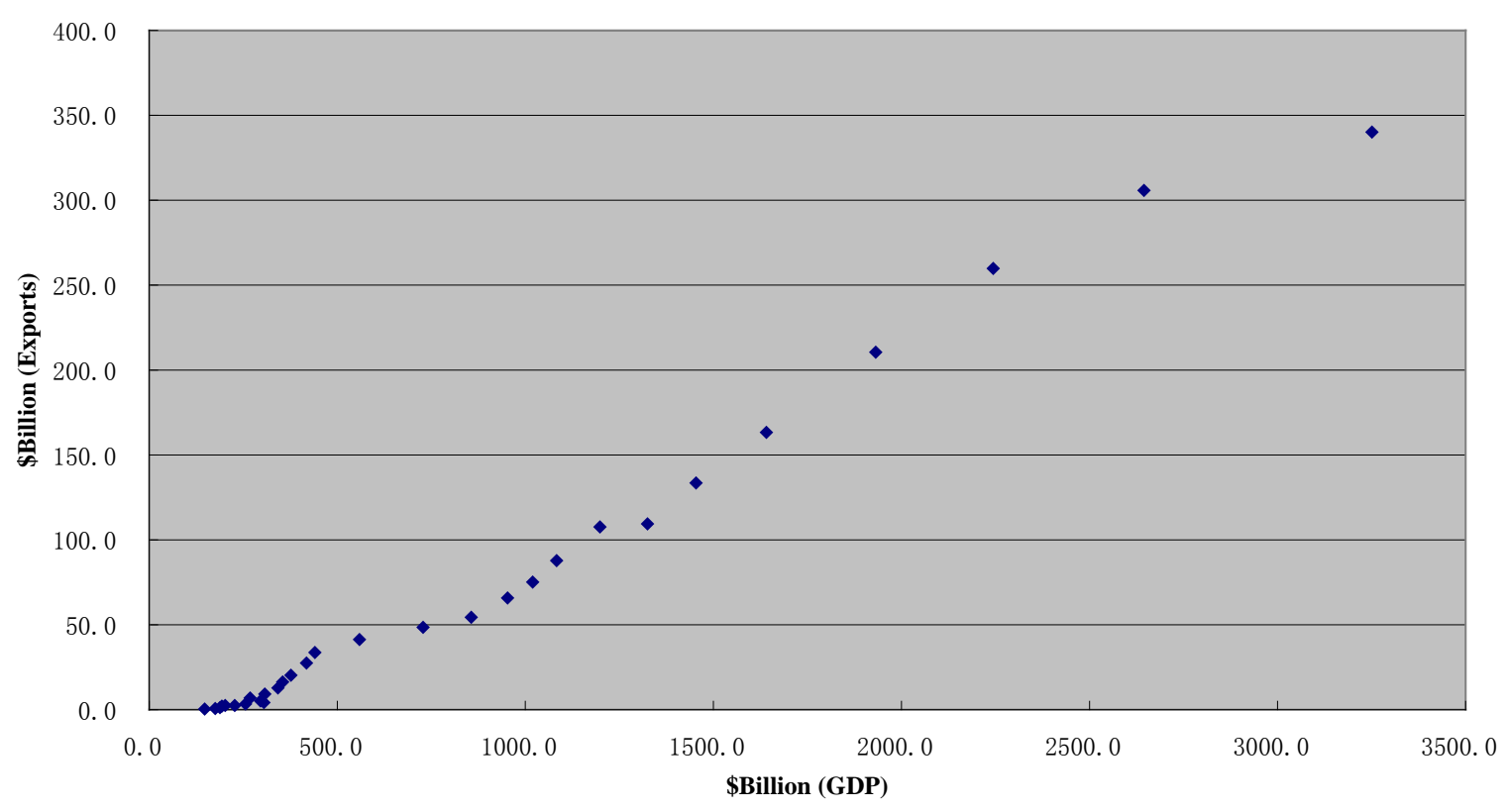

Figure 9. Chian’s GDP \& Chian’s exports to US.

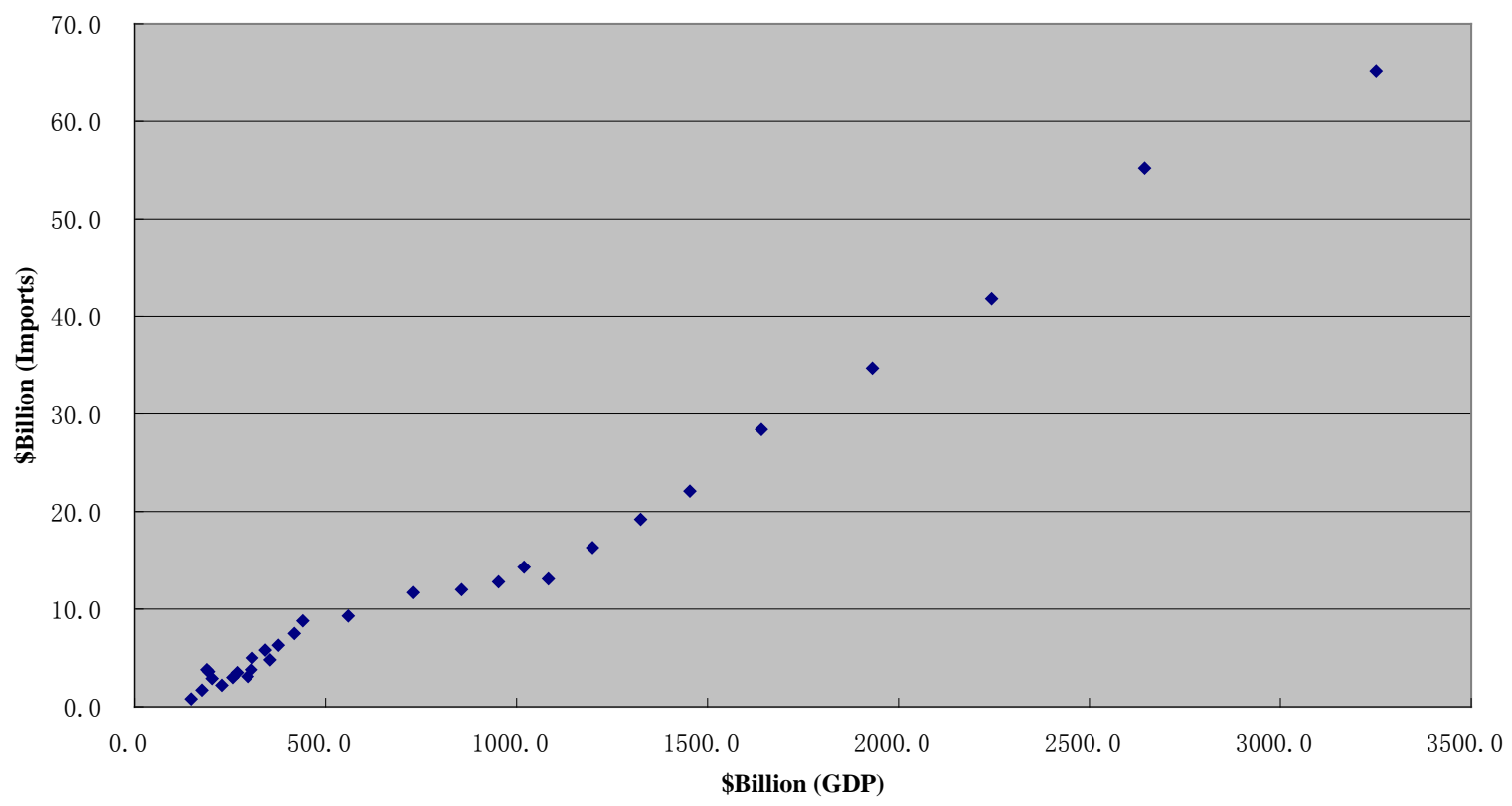

Figure 10. China’s GDP \& China’s imports from US.

Table 4. Correlation coefficient of China's GDP and China’s exports to US (1978-2007).

\begin{tabular}{ccc}
\hline & China's GDP & China's Exports to US \\
\hline $\begin{array}{c}\text { China's GDP } \\
\text { China's Exports to US }\end{array}$ & 1 & 1 \\
\hline & 0.993129591 & \\
\hline & & \\
\hline & & \\
\hline & China's GDP & \\
\hline China's GDP & 1 & China's Imports from US \\
\hline China's Imports from US & 0.986524132 & 1 \\
\hline
\end{tabular}


Table 6. Taking logarithm of each individual number in Table 3.

\begin{tabular}{|c|c|c|c|}
\hline & Ln (China's GDP) & Ln (China's Exports from US) & Ln (China's Import from US) \\
\hline 1978 & 4.992471323 & -0.916290732 & -0.223143551 \\
\hline 1979 & 5.168208681 & -0.356674944 & 0.530628251 \\
\hline 1980 & 5.237505227 & 0.182321557 & 1.335001067 \\
\hline 1981 & 5.262690189 & 0.741937345 & 1.280933845 \\
\hline 1982 & 5.308762624 & 0.916290732 & 1.064710737 \\
\hline 1983 & 5.426710581 & 0.916290732 & 0.78845736 \\
\hline 1984 & 5.545567993 & 1.223775432 & 1.098612289 \\
\hline 1985 & 5.719983854 & 1.435084525 & 1.335001067 \\
\hline 1986 & 5.689345427 & 1.648658626 & 1.131402111 \\
\hline 1987 & 5.591732971 & 1.931521412 & 1.252762968 \\
\hline 1988 & 5.727499001 & 2.219203484 & 1.609437912 \\
\hline 1989 & 5.835687546 & 2.549445171 & 1.757857918 \\
\hline 1990 & 5.870990394 & 2.791165108 & 1.568615918 \\
\hline 1991 & 5.931183616 & 3.010620886 & 1.840549633 \\
\hline 1992 & 6.035959787 & 3.314186005 & 2.014903021 \\
\hline 1993 & 6.087910445 & 3.517497837 & 2.174751721 \\
\hline 1994 & 6.326507191 & 3.7208625 & 2.2300144 \\
\hline 1995 & 6.590301048 & 3.881563798 & 2.459588842 \\
\hline 1996 & 6.752387192 & 3.996364154 & 2.48490665 \\
\hline 1997 & 6.859300059 & 4.186619838 & 2.549445171 \\
\hline 1998 & 6.92706759 & 4.318820559 & 2.660259537 \\
\hline 1999 & 6.987767217 & 4.475061501 & 2.57261223 \\
\hline 2000 & 7.088826054 & 4.678420648 & 2.791165108 \\
\hline 2001 & 7.189016784 & 4.69501089 & 2.954910279 \\
\hline 2002 & 7.281936097 & 4.894101478 & 3.095577609 \\
\hline 2003 & 7.403061091 & 5.095589 & 3.346389145 \\
\hline 2004 & 7.566103954 & 5.349485653 & 3.546739687 \\
\hline 2005 & 7.715970702 & 5.559912104 & 3.73289634 \\
\hline 2006 & 7.880312916 & 5.722931293 & 4.010962953 \\
\hline 2007 & 8.086656399 & 5.829239692 & 4.177459469 \\
\hline
\end{tabular}

tween China's economic growth and Sino-US trade.

In the analysis of the influence of Sino-US trade on China's GDP growth, after analyzing the line graphs and scatter plots, it is not difficult to notice that from 1998 to 2007, the growth of China's GDP has linear relations with the volume of total trade with US, or the volume of China's export to US, or the volume of China's imports to US. Moreover, the correlative analysis indicates that the high positive correlation can be observed among them. It is worth noting that the Correlation Coefficient of China's GDP and China's imports from US, 0.997 is the highest among these three different kinds of Correlation Coefficients. Those simple linear regression models show that China's GDP will increase by an average of $\$ 6.797$ billion if the volume of total trade with US increases by $\$ 1$ billion; China's GDP will increase by an average of $\$ 8.137$ billion if the volume of China's exports to US increases by $\$ 1$ billion; China's GDP will increase by an average $\$ 40.718$ billion if the volume of China's imports from US increases by $\$ 1$ billion. The information indicates that, during this period, the correlation between China's GDP and China's imports from US is stronger than the correlation between China's GDP and China's exports to US and its regression coefficient is 40.718, 32.581 higher than the regression coefficient of China's GDP and China's exports to US. However, the year from 1998 to 2007 may not be a good time series 
for it only contains ten observations. So a longer time series is chosen from 1978 to 2007 to test the result again. Both the research of 10-year time series (1998-2007) and the research of 30-year time series (1978-2007) indicate that, if these simple linear regression models are analyzed only from the perspective of mathematics, China's imports from US have a much bigger positive influence on China's GDP growth compared with China's exports to US. Another two mathematical models indicate that China's GDP will increase by $0.455 \%$ if the volume of China's exports to US increases by $1 \%$; China's GDP will increase by $0.825 \%$ if the volume of China's imports from US increases by $1 \%$. Further research is suggested to explore the reasons accounting for the conclusion in this paper from the perspective of Sino-US trade commodity structure.

\section{References}

[1] Andrea, M. (2004) The True Meaning of David Ricardo’s Four Magic Numbers. Journal of International Economics, 62, 433-443.

[2] Lewer, J.J. and Berg, H.V.D. (2003) How Large Is International Trade's Effect on Economic Growth. Journal of Economic Surveys, 17, 363-396. http://dx.doi.org/10.1111/1467-6419.00198

[3] Dong, M. (2000) An Analysis of the Relations between China's Foreign Trade and Economic Growth. Journal of Northwest University, 30, 81-85.

[4] Yao, L. (2001) An Analysis on the Contribution of Foreign Trade to China’s Economic Growth. Statistical Research, 18, 20-22.

[5] Shen, G. and Gu, A.Y. (2007) Revealed Comparative Advantage, Intra-industry Trade and the US Manufacturing Trade Deficit with China. China \& World Economy, 15, 87-103. http://dx.doi.org/10.1111/j.1749-124X.2007.00094.X 
Scientific Research Publishing (SCIRP) is one of the largest Open Access journal publishers. It is currently publishing more than 200 open access, online, peer-reviewed journals covering a wide range of academic disciplines. SCIRP serves the worldwide academic communities and contributes to the progress and application of science with its publication.

Other selected journals from SCIRP are listed as below. Submit your manuscript to us via either submit@scirp.org or Online Submission Portal.
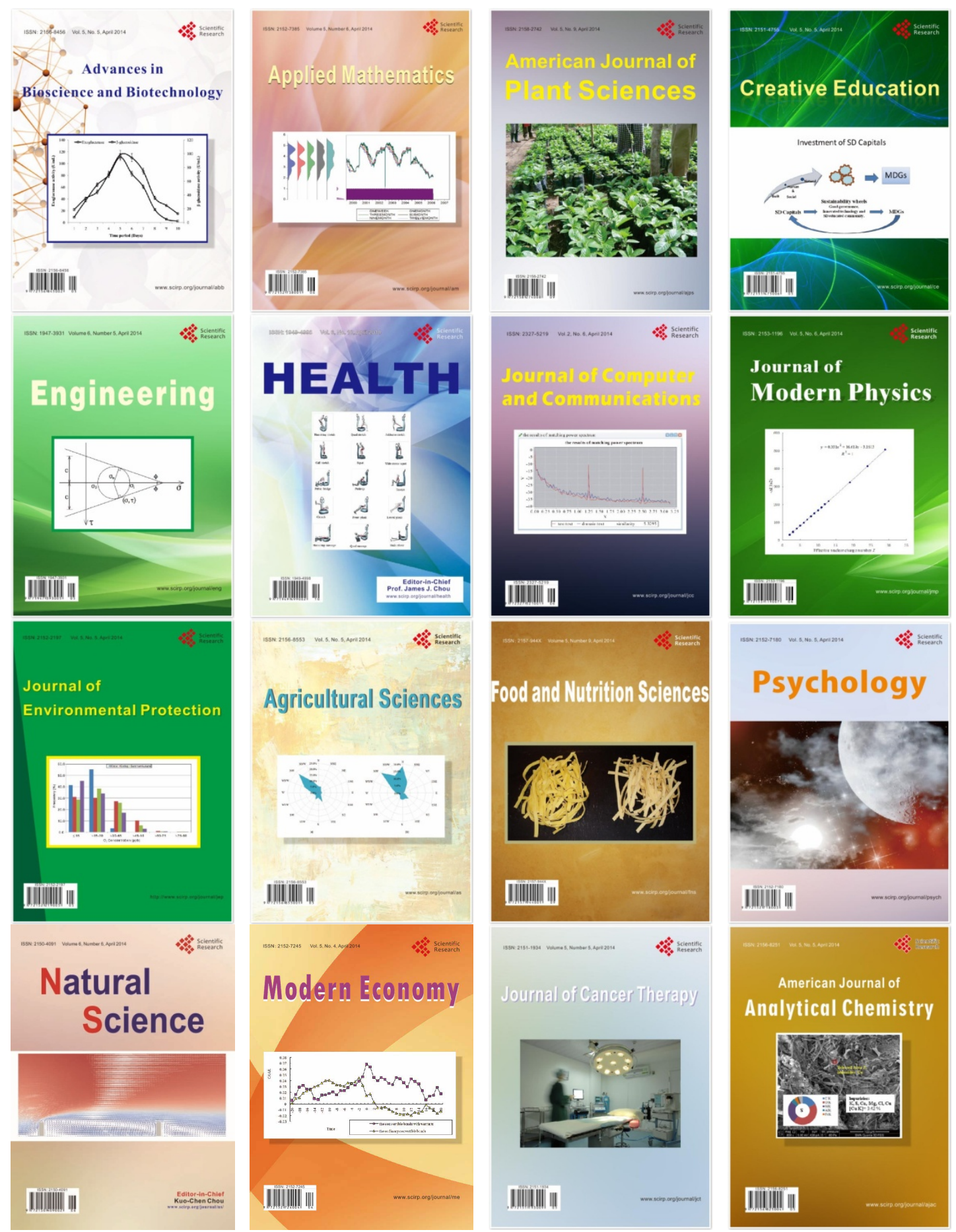